\title{
Reproductive biology of Leptodactylus fuscus (Anura, Leptodactylidae) in the subtropical climate, Rio Grande do Sul, Brazil
}

\author{
Franciéle P. Maragno \& Sonia Z. Cechin
}

Departamento de Biologia, Universidade Federal de Santa Maria, Av. Roraima, 1000, Cidade Universitária, Bairro Camobi, $97105-$ 900 Santa Maria, RS, Brazil. (fmaragno@gmail.com; cechinsz@ccne.ufsm.br)

\begin{abstract}
The aim of this study was to characterize, for the central region of the State of Rio Grande do Sul, Brazil, the reproductive biology of Leptodactylus fuscus (Schneider, 1799), based on the analysis of gonadal development of males and females, reproductive effort, size-fecundity relationships, and occurrence of sexual dimorphism in body size. Mature individuals were found from October 1996 to February 1997 and from October 1997 to December 1997. The highest input of juveniles in the population was recorded in March 1997. There was a positive and significant correlation between the number of mature individuals and the mean monthly temperature. The population did not present sexual dimorphism in size. Males presented significant correlation only between snout-vent length and testes length. All females had oocytes at four different maturation stages and there were no significant correlations regarding size-fecundity variables. The correlation between ovarian size factor and females snout-vent length was not significant either. The main difference between this population and those that inhabit tropical climate was that temperature was responsible for stimulating the reproduction activity, instead of rainfall.
\end{abstract}

KEYWORDS. Amphibians, reproduction, subtropical climate.

RESUMO. Biologia reprodutiva de Leptodactylus fuscus (Anura, Leptodactylidae) em clima subtropical, Rio Grande de Sul. O objetivo do estudo foi caracterizar, para a região central do Rio Grande do Sul, a biologia reprodutiva de Leptodactylus fuscus (Schneider, 1799) a partir da análise do desenvolvimento gonadal de machos e fêmeas, esforço reprodutivo, relações de tamanhofecundidade e existência de dimorfismo sexual em relação ao tamanho corporal. Indivíduos maduros foram encontrados de outubro/ 1996 a fevereiro/1997 e outubro/1997 a dezembro/1997. Em março de 1997, houve o maior acréscimo de indivíduos jovens na população. Houve correlação positiva e significativa entre o número de indivíduos maduros coletados e a temperatura média mensal. A população não apresentou dimorfismo sexual. Para os machos, houve correlação significativa apenas entre comprimento corporal e comprimento dos testículos. Todas as fêmeas possuíam ovócitos em quatro diferentes estágios de maturação e não foi observada nenhuma correlação significativa entre as variáveis de tamanho-fecundidade. A correlação entre fator tamanho do ovário e comprimento corporal também não foi significativa. A principal diferença entre esta população e as que habitam clima tropical foi o efeito da temperatura como estímulo da atividade reprodutiva, ao invés de chuva.

PALAVRAS-CHAVE. Anfíbios, reprodução, clima subtropical.

Amphibian reproductive cycles are under hormonal control, which responds to environmental variation. Anurans from tropical regions tend to present continuous reproductive cycles; however, they reproduce in the season during which rainfall is sufficient to provide oviposition sites. On the other hand, in temperate and subtropical climates, temperature seems to be the main factor that stimulates the onset of the reproductive period (Duellman \& Trueb, 1994).

Leptodactylus Fitzinger, 1826 is divided into five large species groups, including the $L$. fuscus group (HEYER, 1969). In this group reproduction generally occurs during rainy periods with high temperature. Males dig subterranean nests close to water bodies and attract females to enter, where oviposition occurs. Eggs are deposited in foam produced by the pair and tadpoles develop up to a certain stage inside the nest, which is destroyed by flooding or inundated when rains start, thus releasing the larvae to complete their development in the water (HEYER, 1969).

Leptodactylus fuscus (Schneider, 1799) is widely distributed from Panama to Argentina (HeYer, 1978). Reproductive biology and behavior of this species were investigated in Trinidad (KenNY, 1969) and French Guyana (LESCURE, 1972) with the description of burying nest. Seasonality and embryonic development were studied in Venezuela (Solano, 1987). In his revision of the fuscus group, HeYer (1978) considered L. fuscus a unique species according to morphologic issues. After that, strong genetic differentiation was observed within L. fuscus populations along its distribution (HEYER \& REID, 2003; CAMARGO et al., 2006).

In Brazil, many studies were carried out on L. fuscus. In Roraima, reproductive biology and mating behavior were described (MARTINS, 1988). In the southeast of Brazil, Brasileiro et al. (2005) and Oliveira-Filho et al. (2005) also studied seasonality reproductive patterns. In Pantanal of Mato Grosso do Sul, the reproduction occurs during rainy season (Avila \& Ferreira, 2004) and the reproductive biology was studied by PRADO \& HADDAD $(2003,2005)$.

Recently, a revision on $L$. fuscus reproductive ecology indicated that the species has a high reproductive plasticity (LuCAS et al., 2008). For the subtropical region, males of $L$. fuscus vocalize mainly in the warmets months of the year (Вотн et al., 2008; SANTOS et al., 2008). Even though the reproductive biology of $L$. fuscus was well studied in tropical areas, there are no studies in subtropical climate.

Thus, the aim of this study is to characterize the reproductive biology of Leptodactylus fuscus based on the analysis of gonadal development of males and females, reproductive effort, size-fecundity correlation and existence of sexual dimorphism in body size, at a locality in the central region of Rio Grande do Sul State, Brazil. 


\section{MATERIAL AND METHODS}

The study area is located in the municipality of Santa Maria, central region of the State of Rio Grande do Sul, Brazil (Fig. 1). Sampling was carried out from October 1996 to March 1998 in the Campo de Instrução do Exército de Santa Maria (CISM), which is characterized as a deciduous seasonal forest (Veloso \& Goes- Filho, 1982) but currently presents anthropic alterations. There are natural fields near the study area.

According to Köppen's system classification the climate in the region is subtropical humid. The mean annual temperature oscillates from 17.9 to $19.2^{\circ} \mathrm{C}$. However the four seasons are well defined, with summer temperatures reaching about $40^{\circ} \mathrm{C}$ and winter temperatures, $0^{\circ} \mathrm{C}$. Rainfall is regular throughout the year with annual rainfall index from $1500 \mathrm{~mm}$ to $1750 \mathrm{~mm}$. March, November and December are the months with lower rainfall (PEREIRA et al., 1989).

Pitfall traps with drift fences (barrels of 100 1) were used to sample the population of the CISM (CECHIN \& MARTINS, 2000). Three lines of ten containers were installed: one line in the natural grassfield, one along the forest border and one inside the forest. The traps remained open during all study, from October 1996 to April 1998, and were inspected three times a week. The individuals trapped were deposited in the scientific collection of the Zoology Section at Universidade Federal de Santa Maria, Rio Grande do Sul.

Following fixation in $10 \%$ formalin and transference to $70 \%$ ethanol, snout-vent length (SVL) and mass were measured for each individual using a caliper (resolution 0.1 $\mathrm{mm}$ ) and a precision scale (resolution $0.1 \mathrm{~g}$ ), respectively. The testes length was measured using a stereomicroscope

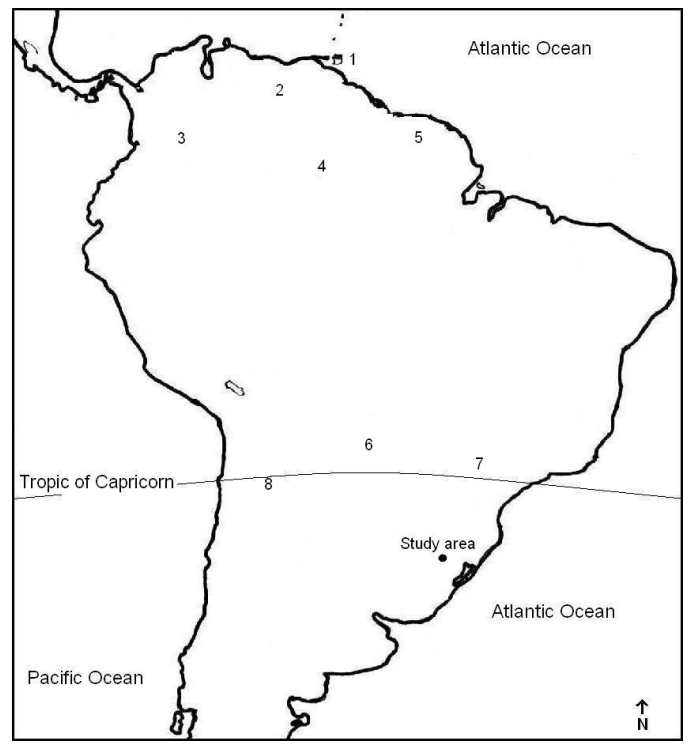

Figure 1. Study area localization, central region of Rio Grande do Sul, Brazil. Studies on Leptodactylus fuscus also developed in this region SANTOS et al., 2008 and Bотн et al., 2008. Numbers 1 to 8 refers to studies with this species along its distribution: (1) KenNy, 1969 in Trinidad; (2) Solano, 1987 in Venezuela; (3) Bernal et al., 2004 in Colombia; (4) Martins, 1988 in Roraima; (5) Lescure, 1972 in French Guiana; (6) Avila \& Ferreira, 2004; Prado \& Haddad, 2003; 2005 and Arzabe \& Prado, 2006 in Mato Grosso do Sul; (7) Rossa-Feres et al., 1999; Toledo et al. 2003; Brasileiro et al., 2005; Oliveira-Filho et al., 2005 and Lucas et al. 2008 in São Paulo; (8) VAIRA, 2002 in Argentina. The localization number presents only a reference of studies areas in the South America. with ocular scale and mass using a precision scale with resolution $0.0001 \mathrm{~g}$. In order to assess maturity, monthly samples of testes were prepared for histological sections survey. Males with spermatozoa in the seminiferous tubules were considered mature. Males with SVL larger than the smallest mature male were considered mature. After histology observations, the pigmentation of vocal sacs was also checked to evaluate male maturity. Analyses were based on the left testis. The following size-fecundity correlations were investigated for mature individuals: 1 . SVL $\mathrm{x}$ testes length; 2. SVL $x$ testes mass; 3 . body mass $x$ testes length; 4 . body mass $\mathrm{x}$ testes mass.

Ovaries were classified by maturity following to HeRMOSILLA et al. (1986), with modifications for this species. It is known that in this species, oocytes are not pigmented (HEYER, 1969). Those with darker yellow coloration and pronounced larger size were considered post-vitellogenic (mature). Mature oocytes of both ovaries were counted and the diameter of the ten largest ones was measured for each female. To facilitate counting, the oocytes were separated by immersion into a solution of 3\% sodium hypochlorite. Fecundity was estimated based on the ovarian complement (number of mature oocytes in the ovary) and on the "ovary size factor" (OSF) (Duellman \& CRUMP, 1974), which correlates number and size of post-vitellogenic oocytes to body length: OSF = OC x DO / SVL, where OC: ovarian complement; DO: mean diameter of the ten largest postvitellogenic oocytes; $\mathrm{SVL}=$ females snout-vent length. Sizefecundity correlations were evaluated among the following variables: 1. Females SVL x ovarian complement; 2 . SVL x mass of mature ovaries; 3 . Body mass $\mathrm{x}$ ovarian complement; 4. Body mass $x$ mass of mature ovaries.

Reproductive effort was measured as percentage of gonad mass in relation to body mass (PRADO et al., 2000). For males, the value recorded for the left testis was multiplied by two.

The Spearman $\left(\mathrm{r}_{\mathrm{s}}\right)$ Correlation Coefficient was used to calculate correlation between size and fecundity, OSF and female SVL, and temperature and rainfall and abundance of mature individuals. Sexual dimorphism in SVL was tested through Student's $t$ Test. Normality was evaluated with the Shapiro-Wilk test.

\section{RESULTS}

Mature individuals were found from October 1996 to February 1997 and from October 1997 to December 1997. Monthly mean temperature was higher in January and lower in June and July. The monthly rainfall varied along the year, with the most rainy months at the end of 1997 (Fig. 2).

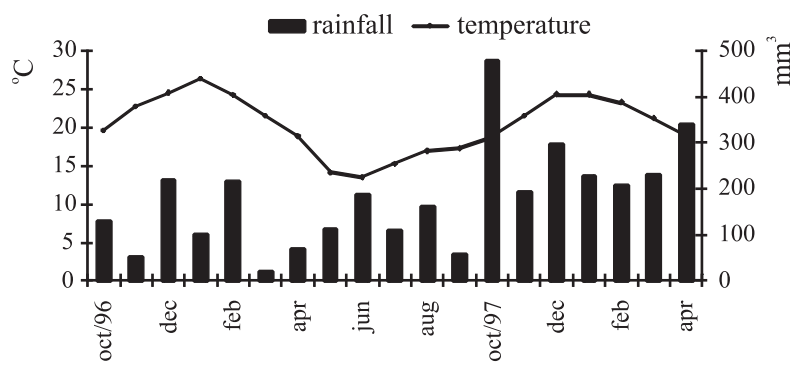

Figure 2. Monthly mean temperature and monthly accumulated rainfall for Santa Maria, Rio Grande do Sul, Brazil, from October 1996 to April 1998. 
There was a significant positive correlation between the number of mature individuals and the mean monthly temperature $\left(\mathrm{r}_{\mathrm{s}}=0.539 ; \mathrm{p}=0.02 ; \mathrm{n}=18\right)$, but there was no correlation to the mean monthly rainfall $\left(r_{s}=0.117 ; p=\right.$ $0.643 ; \mathrm{n}=18)$.

The population had no sexual dimorphism in SVL $(\mathrm{t}=1.55 ; \mathrm{p}=0.132 ; \mathrm{FD}=28)$, but females were larger in body mass than males $(\mathrm{t}=3.00 ; \mathrm{p}=0.005 ; \mathrm{FD}=28)$, (Tab. I). Among the testes analyzed by histological sections, $18(43.9 \%)$ had spermatozoa in the seminiferous tubules. Of these, 13 had vocal sacs pigmented and five had not. In addition, 11 individuals had larger SVL than the smallest mature male. Eight of them had vocal sacs pigmented and three had not. There was significant correlation only between SVL and testes lengthsize $\left(r_{s}=0.45 ; p=0.016\right.$; $\mathrm{n}=29$ ).

Twelve mature females of $L$. fuscus were collected and all had oocytes in four different stages: 1: previtellogenic - with no accumulation of yolk in the cytoplasm, small and transparent; 2: primary vitellogenesis - accumulation of vitellus started, small and whitish; 3: late vitellogenesis - larger accumulation of vitellus, slightly larger and yellow; 4 : post-vitellogenic - mature oocytes, large and dark yellow. Some females presented a small number of post-vitellogenic oocytes $($ minimum $=42)$. No significant correlation $(\mathrm{p}>0.05 ; \mathrm{n}=$ 12) was found to the size-fecundity variables. The correlation between OSF and SVL was not significant $\left(\mathrm{r}_{\mathrm{s}}\right.$ $=-0.09 ; \mathrm{p}=0.78 ; \mathrm{n}=12$ ).

The number of juveniles in the population greatly increased in March 1997. The smallest juvenile caught in that month had $17.07 \mathrm{~mm}$; the smallest juvenile was caught in January and had $15.90 \mathrm{~mm}$. During the first three months of the year (Jan - Mar) juveniles of different sizes were found.

\section{DISCUSSION}

The studied population of $L$. fuscus may be classified in the prolonged reproductive activity pattern, as found for a tropical population at Corumbá, western Brazil (PRADO \& HADDAD, 2005). Analysis of gonads of the present study population indicated that reproduction occurred from October to March. This result agrees with that of SANTos et al. (2008), who observed L. fuscus engaged in vocalization activity from November to March in our study region.

All previous studies with $L$. fuscus in tropical areas identified rainfall as the most important factor for the onset of reproduction (LuCAs et al., 2008). In our study, the capture of mature individuals showed positive correlation only with monthly temperature. The number of vocalizing males for the whole anuran community also showed correlation with monthly temperature in a previous study conducted in this same area (SANTOS et al., 2008). In south Brazil, characterized by a subtropical climate, temperature presents high variation along the year, while rainfall is observed well distributed roundyear (with no dry season). Thus, the reproductive behavior variation of $L$. fuscus is a consequence of this climatic variation. Besides, the population studied here reacted to a different climate factor from those of the same genetic lineage, but that inhabiting tropical environment (CAMARGO et al., 2006; LuCAS et al., 2008).

The population of $L$. fuscus here studied did not present sexual dimorphism in SVL. The length of males and females was similar to that found by Solano (1987), in Venezuela. On the other hand, length of males and females was larger than that found by MARTINS (1988), in Roraima and smaller than found by LuCAs et al. (2008), in São Paulo, Brazil. Among the studies about the species

Table I. Reproductive characteristics of Leptodactylus fuscus (Schneider, 1799) for individuals caught in Rio Grande do Sul, from October 1996 to April 1998, and characteristics from studies with the species along its distribution (MFSVL, mean females SVL; MMSVL, mean males SVL; MFBM, mean females body mass; MMBM, mean males body mass; DPvO, diameter of post-vitellogenic oocytes; NPvO, number of post-vitellogenic oocytes; MOM, mean ovary mass; MOSF, mean ovary size factor; TM, testes mass; TL, testes length; MMRE, mean reproductive effort; MFRE, mean female reproductive effort).

\begin{tabular}{|c|c|c|c|c|c|c|}
\hline Study & This study & $\begin{array}{c}\text { LuCAS et al., } \\
2008\end{array}$ & $\begin{array}{c}\text { Prado \& HADDAD, } \\
2003\end{array}$ & $\begin{array}{c}\text { PRADO \& HADDAD, } \\
2005\end{array}$ & Martins, 1988 & Solano, 1987 \\
\hline MFSVL (mm) & $43.7(41.9-46.3)$ & 45.6 & & $43.6(40-46.2)$ & 39.5 & 42 \\
\hline $\operatorname{MMSVL}(\mathrm{mm})$ & $43(39.9-46.8)$ & 43.6 & & & 36.2 & 43 \\
\hline MFBM (g) & $10.4(9.0-13.2)$ & & & $8.6(6.9-11)$ & & \\
\hline MMBM (g) & $8.92(7-11.2)$ & & 7.7 & & & \\
\hline $\mathrm{DPvO}(\mathrm{mm})$ & $1.5(1.2-1.6)$ & $1.0-2.0$ & & $2.2(2.1-2.3)$ & 1.8 & 2 \\
\hline $\mathrm{NPvO}$ & $191.8(42-441)$ & $128-385$ & & $214(185-248)$ & $182-248$ & $245-296$ \\
\hline MOM (g) & 0.72 & & & $0.58(0.18-0.87)$ & & \\
\hline M OSF & $6.47(0.22-1.0)$ & & & & & \\
\hline TM $(\mathrm{g})$ & $0.003(0.0012-0.0052)$ & & 0.005 & & & \\
\hline $\mathrm{TL}(\mathrm{mm})$ & $2.3(1.6-3.0)$ & & & & & $1.6-2.1$ \\
\hline MMRE (\%) & $0.07(0.015-0.05)$ & & 0.06 & & & \\
\hline MFRE (\%) & $7.47(2.6-10.8)$ & & & $6.8(2.6-12.6)$ & & 11 \\
\hline
\end{tabular}


only Martins (1988) and LuCAS et al. (2008) recorded sexual dimorphism, with females larger than males.

The highest recruitment of juveniles of $L$. fuscus occurred in February and March, which corresponds to the end of the reproductive period. In Venezuela, Solano (1987) observed that, in the laboratory, the metamorphosis of this species takes 50 days and the size of the newly metamorphosed individuals is around 11 to $12 \mathrm{~mm}$, reaching $20 \mathrm{~mm}$ after only two months. If we do not consider population or climate differences, the observation of juveniles of $20 \mathrm{~mm}$ or larger in January 1997 in the present study suggests that clutches were laid in October 1996, which corroborates the findings from gonad analysis that the reproductive activity begins in October. The large number of juveniles captured at the end of the reproductive period is probably related to their displacements searching for shelter to undergo colder months, since the species was not found in the winter (June to August).

The size and mass of anuran testes increase during spermatogenesis due to maturation of the spermatogenic cells (Duellman \& Trub, 1994). This increase was recorded for L. fuscus in this study, since length of testes was positively correlated to the SVL. In the present study, some males with mature tests had not pigmented vocal sacs. The development of this secondary characteristic may have been retarded in these individuals. On the other hand, some males with pigmented vocal sacs had no mature testes. Only the left testis was evaluated here and it is possible that these individuals had spermatozoids on the right test. Therefore, these results highlight the importance of carrying out histological analysis of at least one testis to assess male maturity.

Males of a population of $L$. fuscus studied in Mato Grosso do Sul (PRADO \& HADDAD, 2003) presented smaller mean body mass and reproductive effort than those found in this study; however, the mean testes mass was larger in that study. Otherwise, these populations may be considered very similar. CAMARGO et al. (2006) found that the mtDNA data support the hypothesis of three groups within L. fuscus, occurring in northern, southern and south-eastern, and western South America. They did not evaluate individuals from Pantanal and Rio Grade do Sul, but it is possible that these two populations belong to the same group.

High gonad investment in males may indicate sperm competition, as recorded by PRADO \& HADDAD (2003) in Leptodactylus chaquensis Cei, 1950 and L. podicipinus (Cope, 1862). Their record for $L$. fuscus was similar to that found in this study. The low reproductive effort found in both studies is probably related to the reproductive strategy used by the species, in which the male builds a subterranean nest, attracts a female and the clutch is laid there, which may prevent eliminates sperm competition.

In comparison to this study, in Mato Grosso do $\mathrm{Sul}$, females of $L$. fuscus had smaller body mass and lighter ovaries, but contained larger and fewer post-vitellogenic oocytes (PRADO \& HADDAD, 2005). The population studied here presented most of the body filled by the gonads, which were heavier probably because the postvitellogenic oocytes were smaller but occurred in greater number. In southeast Brazil, the oocytes were larger than observed here and found in lower numbers (LuCAS et al., 2008). In Roraima, post-vitellogenic oocytes had similar size of that recorded herein, but found in a smaller number. This could be related with the small body size of mature females from Roraima (MARTINs, 1988). In Venezuela (SolAno, 1987), female reproductive effort was higher than in this study, probably due to larger oocytes found in a great number, once the body size was similar. The trend to decrease egg number with the increase in egg diameter was suggested to be related to more terrestrial reproductive modes (HEYER, 1969). Comparing to other studies, the population herein is the one that least represents this trend, but the values found are in accordance to what HeYER (1969) proposed for the $L$. fuscus group.

The absence of correlation between the sizefecundity variables in females of this study was also verified by Solano (1987) and Prado \& Haddad (2005) in other populations of L. fuscus. Only MARTINs (1988) found significant correlation between SVL and number of eggs. According to CRUMP (1974), the ovary size factor increases together with the increase of the female SVL in each reproductive mode, but this correlation was not verified in this study. Neither was it recorded by Solano (1987), which suggests a hypothesis of influence of nutritional and environmental condition on the oocytes production.

The reproductive biology of $L$. fuscus in southern Brazil presented some differences comparing to other populations already studied. The main difference concerns the factor responsible for stimulating the reproduction, which is rainfall in seasonally dry tropical regions whereas in the area of this study, where rainfall is well distributed along the year, temperature played this role. Such data demonstrate the environmental plasticity of the species and evidence that populations of the same species may present different patterns according to the climate under which they live.

Acknowledgments. We thank Janaine Melchiors for the orientation with reproductive biology, Cynthia P. Prado and the anonymous reviewers for the suggestions on the manuscript. We also thank to the Campo de Instrução do Exército de Santa Maria (CISM) for allowing the study in its property.

\section{REFERENCES}

Arzabe, C. \& Prado, C. P. A. 2006. Distinct architectures of subterranean nests in the genus Leptodactylus of the fuscus Group (Anura, Leptodactylidae). Herpetological Review 37(1):23-26.

Ávila, R. W. \& Ferreira, V. L. 2004. Riqueza e densidade de vocalizações de anuros (Amphibia) em uma área urbana no município de Corumbá, Mato Grosso do Sul, Brasil. Revista Brasileira de Zoologia 21(4):887-892.

Bernal, M. H.; Montealegre, D. P. \& PÁez, C. A. 2004. Estudio de la vocalización de trece especies de anuros del municipio del Ibagué, Colombia. Revista de la Academia Colombiana de Ciencias XXVIII(108):385-390.

Both, C.; Kaefer, I. L.; Santos, T. G. \& Cechin, S. Z. 2008. An austral anuran assemblage in the Neotropics: seasonal occurrence correlated with photoperiod. Journal of Natural History 42:205-222.

Brasileiro, C. A.; Sawaya, R. J.; Kiefer, M. C.; \& Martins, M. 2005. Amphibians of an open Cerrado fragment in southeastern Brazil. Biota Neotropica 5(2):1-17.

Camargo, A.; SÁ, R. O. DE \& Heyer, W. R. 2006. Phylogenetic 
analyses of mtDNA sequences reveal three cryptic lineages in the widespread neotropical frog Leptodactylus fuscus (Schneider,1799) (Anura, Leptodactylidae). Biological Journal of Linnean Society 87:325-341.

Cechin, S. Z. \& Martins, M. 2000. Eficiência de armadilhas de queda (pitfall traps) em amostragens de anfíbios e répteis no Brasil. Revista Brasileira de Biologia 17(3):729-740.

CRump, M. L. 1974. Reproductive strategies in a tropical anuran community. Miscellaneous Publication of the Museum of Natural History 61:1-68.

Duellman, W. E. \& Crump, M. L. 1974. Speciacion in frogs of the Hyla parviceps group in the upper Amazon Basin. Occasional Papers of the Museum of Natural History 23:1-40.

Duellman, W. E. \& Trueb, L. 1994. Biology of Amphibians. Baltimore, The Johns Hopkins University. 670p.

Hermosilla, I. B.; Colomas, L. S.; Weigerth, G.; Reyest, T. \& Gomezo, V. 1986. Caracterizacion del ovario de la "rana chilena" Caudiverbera caudiverbera (Linné, 1758) (Anura, Leptodactylidae). Boletín de la Sociedad de Biología de Concepción 54:103-115.

Heyer, W. E. 1969. The adaptative ecology of the species groups of the genus Leptodactylus (Amphibia, Leptodactylidae). Evolution 23(9):421-428.

___. 1978. Systematics of the fuscus group of the frog genus Leptodactylus (Amphibia, Leptodactylidae). Natural History Museum 29:1-85.

Heyer, W. E. \& Reid, Y. R. 2003. Does advertisement call variation coincide with genetic variation in the genetically diverse frog taxon currently known as Leptodactylus fuscus (Amphibia: Leptodactylidae)? Anais da Academia Brasileira de Ciências 75(1):39-54.

Kenny, J. S. 1969. The Amphibian of Trinidad. Studies on the Fauna of Curaçao 29:1-78.

Lescure, J. 1972. Contribuition a l'étude des amphibiens de Guyane Française II. Leptodactylus fuscus (Schneider). Observations écologiques. Annual Museum History Natural Nice 1:91-100.

Lucas, E. M.; Brasileiro, C. A.; Oyamaguchi, H. M. \& Martins, M. 2008. The reproductive ecology of Leptodactylus fuscus (Anura, Leptodactylidae): new data from natural temporary ponds in the Brazilian Cerrado and a review throughout its distribution. Journal of Natural History 42:2305-2320.
Martins, M. 1988. Biologia reprodutiva de Leptodactylus fuscus em Boa Vista, Roraima (Amphinia: Anura). Revista Brasileira de Biologia 48(4):969-977.

Oliveira-Filho, J. C.; Costa, H. C. M. \& Braga, U. M. L. 2005. Egg-laying and foam-beating in Leptodactylus fuscus (Anura, Leptodactylidae). Biota Neotropica 5(2):1-2.

Pereira, P. R. B.; Netto, L. R. G.; Borin, C. J. A. \& Sartori, M. G. B. 1989. Contribuição à geografia física do município de Santa Maria: unidades de paisagem. Geografia - Ensino \& Pesquisa 3:37-68.

Prado, C. P. A. \& Haddad, C. F. B. 2003. Testes size in Leptodactylid frogs and occurrence of multimale spawning in the genus Leptodactylus in Brazil. Journal of Herpetology 37(2):354-362.

2005. Size-fecundity relationships and reproductive investment in female frogs in the Pantanal, south-western Brazil. Herpetological Journal 15:181-189.

Prado, C. P. A.; Uetanabaro, M. \& Lopes, F. S. 2000. Reproductive strategies of Leptodactylus chaquensis and L. podicipinus in the Pantanal, Brasil. Journal of Herpetology 34(1):135-139.

Rossa-Ferres, D. C.; Menin, M. \& Izzo, T. J. 1999. Ocorrência sazonal e comportamento territorial em Lpetodactylus fuscus (Anura, Leptodactylidae). Iheringia, Série Zoologia, 87:93-100.

Santos, T. G.; Kopp, K.; Spies, M. R.; Trevisan, R. \& Cechin, S. Z. 2008. Distribuição temporal e espacial de anuros em área de Pampa, Santa Maria, RS. Iheringia, Série Zoologia, 98(2):244-253.

Solano, H. 1987. Algunos aspectos de la biologia reproductiva del sapito silabador Leptodactylus fuscus (Schneider) (Amphibia: Leptodactylidae). Amphibia-Reptilia 8:111-128.

Toledo, L. F.; Zina, J. \& Haddad, C. F. B. 2003. Distribuição espacial e temporal de uma comunidade de anfíbios anuros do município de Rio Claro, São Paulo, Brasil. Holos Environment 3(2)136-149.

VAIRA, M. 2002. Anurans of a subtropical montane forest in northwestern Argentina: ecological survey and a proposed list of species of conservation concern. Biodiversity Conservation 11:1047-1062.

Velloso, H. P. \& Goes-Filho, L. 1982. Fitogeografia Brasileira: classificação fisionâmica-ecológica da vegetação neotropical Boletin Técnico Radam-Brasil, Série Vegetação 1:1-80.

Recebido em maio de 2007. Aceito em março de 2009. ISSN 0073-4721

Artigo disponível em: www.scielo.br/isz 